\title{
Environmental Effect and
}

\section{Acetylsalicilyc Acid on} Agronomic Performance of Three Sweet Potato Genotypes

\author{
Sergio Contreras Liza*, Hebert Huamán Sáenz, Oscar Ciprian Torres \\ School of Agronomy (Escuela Académica de Agronomía), Universidad Nacional José Faustino Sánchez Carrión, Huacho, Perú \\ Email: *scontreras@unjfsc.edu.pe
}

How to cite this paper: Liza, S.C., Sáenz, H.H. and Torres, O.C. (2016) Environmental Effect and Acetylsalicilyc Acid on Agronomic Performance of Three Sweet Potato Genotypes. Open Access Library Journal, 3: e3009. http://dx.doi.org/10.4236/oalib.1103009

Received: September 11, 2016

Accepted: October 9, 2016

Published: October 13, 2016

Copyright $\odot 2016$ by authors and Open Access Library Inc.

This work is licensed under the Creative Commons Attribution International License (CC BY 4.0)

http://creativecommons.org/licenses/by/4.0/

\section{(c) (i) Open Access}

\begin{abstract}
The present research on the effect of chemical inducers of systemic acquired resistance in sweet potato (Ipomoea batatas Lam.) was developed during 2012-2013 at Cañete, Peru. The objective was to determine the effectiveness of some chemicals used for the induction of systemic resistance on agronomic performance of sweet potato in order to improve overall health in the fields, increase of plant survival and reduce the impact of agrochemical applications. Three sweet potato genotypes were sown in RCBD with 3 replications during in the winter of 2012 and summer of 2013. Additionally two chemical inducers of SAR, potassium phosphite $\left(2.5 \mathrm{ml} \cdot \mathrm{L}^{-1}\right)$ and acetylsalicylic acid $\left(100 \mathrm{mg} \cdot \mathrm{L}^{-1}\right)$ were applied plus untreated control plots. The results indicated that there were no statistical differences $(p>0.05)$ for root weight.plant ${ }^{-1}$ or survival percentage and there were statistical differences in weight of foliage.plant ${ }^{-1}$ for chemical treatments. Statistical differences were found between seasons and interaction of seasons and genotypes for foliage weight, suggesting a physiological effect by the application of inducing systemic resistance chemicals on the agronomic performance of sweet potato. It was concluded that specific effect of acetylsalicylic acid increased the weight of foliage plant ${ }^{-1}$ in genotypes of sweet potato and there were no influences for root yield.
\end{abstract}

\section{Subject Areas}

Agricultural Science

\section{Keywords}

Sweet Potatoes, Systemic Acquired Resistance, Acetylsalicylic Acid, Potassium Phosphite, ANOVA 


\section{Introduction}

Sweet-potato (Ipomea batatas Lam.) ranking third in the tuber roots worldwide, has been the subject of little research worldwide compared with other major crop staples, especially for those less developed countries where sweet-potato is important for food security. For this reason is necessary to assess comprehensive strategies that are possible to adopt by small farmers who produce these roots and tubers, one of which is to identify alternative management of the health of the crops that are available to the sector of poor farmers.

Over $80 \%$ of the area in Peru dedicated to root and tuber crops as potatoes and sweet potatoes, are smallholder agriculture with less than 20 hectares, and potatoes currently is cultivated on about 300,000 hectares nationwide [1]; something similar happens in sweet potatoes though as the area dedicated is about 15,000 hectares, of which Lima region covers more than $60 \%$ of the total sown [2].

Salicylic acid (SA) is a phenolic compound considered as candidate for exogenous applications such as Systemic Acquired Resistance (SAR) activator and aspirin in particular, has been selected as a low-cost, non-phytotoxic product, similar to SA [3]. Usually caused by a local infection, plants respond with a cascade of salicylic aciddependent signaling leading to systemic expression of broad spectrum resistance and lasting resistance, to be effective against fungal, bacterial and viral infections. In the words of Walters [4], systemic resistance has the potential to revolutionize disease control in crops, but still a kind of non-conventional protection for crops.

SAR is elicited by biological compounds, including chitins, ergosterols, glucans, lipopolysaccharides, proteins, peptides, salicylic acid and sphingolipids according to Lyon [5]. The effect of exogenous SA depends on numerous factors such as the species and developmental stage of the plant, the mode of application and the concentration of SA and its endogenous level in a given plant [6].

According to Lebeis et al. [7], biosynthesis and signaling dependent on salicylic acid is required to assemble a normal root microbiome. Salicylic acid modulates colonization of the root by specific bacterial families. Determinants secreted from the root system were search for and it was found that salicylic acid is a major molecule involved in SAR transmission through the root [8].

This research seeks to show the effectiveness of low-cost products and low environmental impact to human health and the ecosystem, such as acetylsalicylic acid and potassium phosphite (FP) to improve agronomic performance in sweet potato fields and identify opportunities for use them on a plan of integrated crop management.

\section{Materials and Methods}

Two separate factorial experiments in sweet-potato under Randomized Complete Block Design (RCBD) were installed at Imperial (Cañete province, $150 \mathrm{~km}$ south of Lima) in two environments, winter 2012 and summer 2013 with the objective to evaluate the effect of two chemical inducers (acetylsalicylic acid and potassium phosphite) reported in the literature [9]-[11] plus a control with no application, on agronomic performance of 
three genotypes of potato (INA100-INIA, C-10, C-50). INA100-INIA [12] as a check genotype (CIP 102033.5), C-50 as orange flesh and C-10 purple flesh experimental clones. Plant material was provided by International Potato Center (CIP) Germplasm Bank at Lima. In order to assess the interaction for sweet potato genotypes and chemical inducers and environments, experimental field design was lay out considering 40 single hill-plots and three replicates each treatment.

Soil analysis at the experimental environments showed a loam soil textural class, slightly alkaline reaction $(\mathrm{pH}=7.9)$, nitrate, phosphate and potassium content of 24,44 and $169 \mathrm{ppm}$, respectively, exchange cation capacity $13.72 \mathrm{meq} \cdot 100^{-1} \mathrm{~g}$ and absence of soluble salts $\left(\mathrm{EC}=2.4 \mathrm{ds} \cdot \mathrm{m}^{-1}\right)$. The average air temperature in winter was $18^{\circ} \mathrm{C}$ and $26^{\circ} \mathrm{C}$ in summer and $85 \%$ relative air humidity; no rain was recorded so irrigation was required during crop seasons.

The applications of products were performed every 2 weeks for acetylsalicylic acid $\left(100 \mathrm{mg} \cdot \mathrm{L}^{-1}\right)$ and were monthly for potassium phosphite $\left(2.5 \mathrm{~g} \cdot \mathrm{L}^{-1}\right)$ as considered in USAID [13]. To prepare the solution of acetylsalicylic acid, pharmaceutical product Aspirin Bayer ${ }^{\circledR}$ was used; it was ground with a mortar and diluted with $10 \mathrm{ml}$ of commercial methyl alcohol (80\%) and then a solution was prepared as stock with distilled water at a concentration of $100 \mathrm{mg} \cdot \mathrm{L}^{-1}$, to be sprayed on plants often than directed. The preparation of potassium phosphite was performed as directed by the manufacturer to the aforementioned doses [10]. The plants in the control plots were sprayed with current water. In both experiments an experimental control handling for constant factors was carried out, and treatments were randomly applied for experimental units in 40 plants- single rows; the experimental design was randomized complete block with 3 replicates per treatment (genotype $\mathrm{x}$ chemical inductor). The variables to evaluate were root fresh weight.plant ${ }^{-1}$, percentage of plant survival at harvest and fresh weight of foliage.plant ${ }^{-1}$. The characteristics were evaluated during the harvest period at 120 days after planting. Plant density was 40,000 plants $\cdot \mathrm{ha}^{-1}$.

The data were processed by InfoStat software [14]; F test for analysis of variance and LSD (Fisher) for mean test $(\mathrm{p}<0.05)$ were used.

\section{Results}

The results of the effect of chemical inducers in sweet potatoes can be illustrates in Table 1 in which the component seasons, was statistically significant $(\mathrm{p}<0.05)$ and the other sources of variation and their interactions, were not significant in both seasons. This suggests that in terms of the inductors used (acetylsalicylic acid and potassium phosphite), they do not seem to affect root yield per plant, and the contribution of environmental factors such as the season or year of planting are more relevant. For percentage of plant survival at harvest, there were no differences for SAR inductors, neither its interactions with environments.

The same can be seen in Figure 1, in which the statistical differences between treatments were not significant. It confirms that for sweet potato root weight in genotypes evaluated, inducing SAR treatments had no statistical effect for both seasons. 
Regarding fresh weight of foliage per plant (Table 1), statistical differences for the interaction of genotypes were found for seasons, which implies that these components are relevant to fresh weight of foliage. In the statistical test between resistance inductors versus control, statistical differences for foliage weight/plant were found, whereas acetylsalicylic acid was superior to both control (T) and potassium phosphite (FP) (Figure 2).

\section{Discussion}

The results of numerous investigations over the past two decades have shown that salicylic acid plays an important role in various aspects of post defense responses to attack

Table 1. Factorial analysis of variance for effect of SAR inductors in three genotypes of sweet potato and two cropping seasons.

\begin{tabular}{|c|c|c|c|c|}
\hline Component & $\mathrm{Df}$ & WRoots/plant & WFoliage/plant & $\%$ Survival \\
\hline Environments & 1 & $38,134^{* *}$ & $33,004^{* *}$ & $3151.04^{* *}$ \\
\hline Blocks & 2 & 0.1030 & 0.1210 & $362.97^{\star}$ \\
\hline Genotypes & 2 & 0.3994 & 0.0219 & $1590.41^{* *}$ \\
\hline SAR Inductors & 2 & 0.1629 & 0.0448 & 156.48 \\
\hline Environments ${ }^{\star}$ Genotypes & 2 & 0.1688 & $0.8226^{* *}$ & 205.69 \\
\hline Environments ${ }^{\star}$ Inductors & 2 & 0.0583 & 0.0034 & 152.16 \\
\hline Genotype ${ }^{\star}$ Inductor & 4 & 0.0672 & $0.0504^{*}$ & 95.59 \\
\hline Env $^{\star}$ Genotype $^{\star}$ Inductor & 4 & 0.0808 & 0.0063 & 22.03 \\
\hline Combined Error & 34 & 0.1302 & 0.0797 & 99.21 \\
\hline Total & 53 & & & \\
\hline
\end{tabular}

${ }^{*}$ Statistical significance in bold, $\mathrm{p}<0.05,{ }^{* *} \mathrm{p}<0.01 . \mathrm{Df}=$ degrees of freedom. MS $=$ medium squares for variance components.

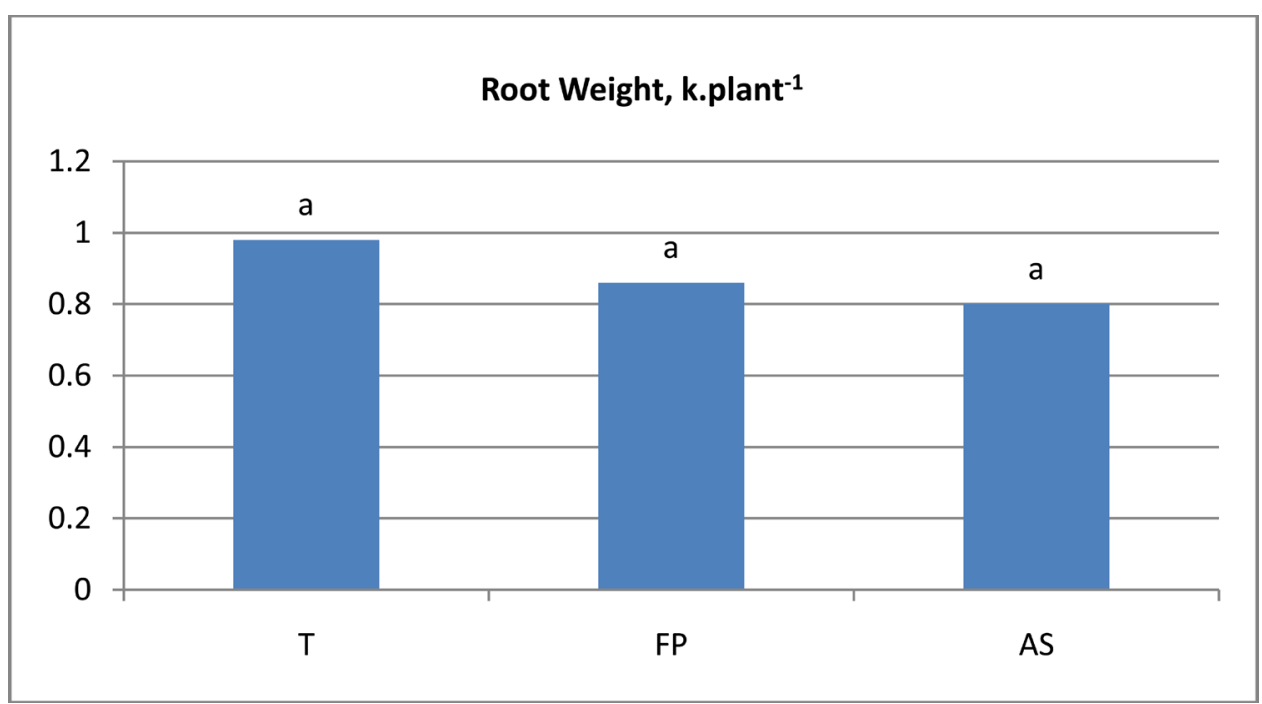

Figure 1. Effect of acetyl salicylic acid and potassium phosphite on the root weight.plant ${ }^{-1}$ in three genotypes of sweet potato and two seasons. $\mathrm{T}=$ control; $\mathrm{FP}=$ Potassium phosphite; $\mathrm{AS}=$ acetyl salicylic acid. Values with the same letter are not significant $(\mathrm{p}>0.05)$. 


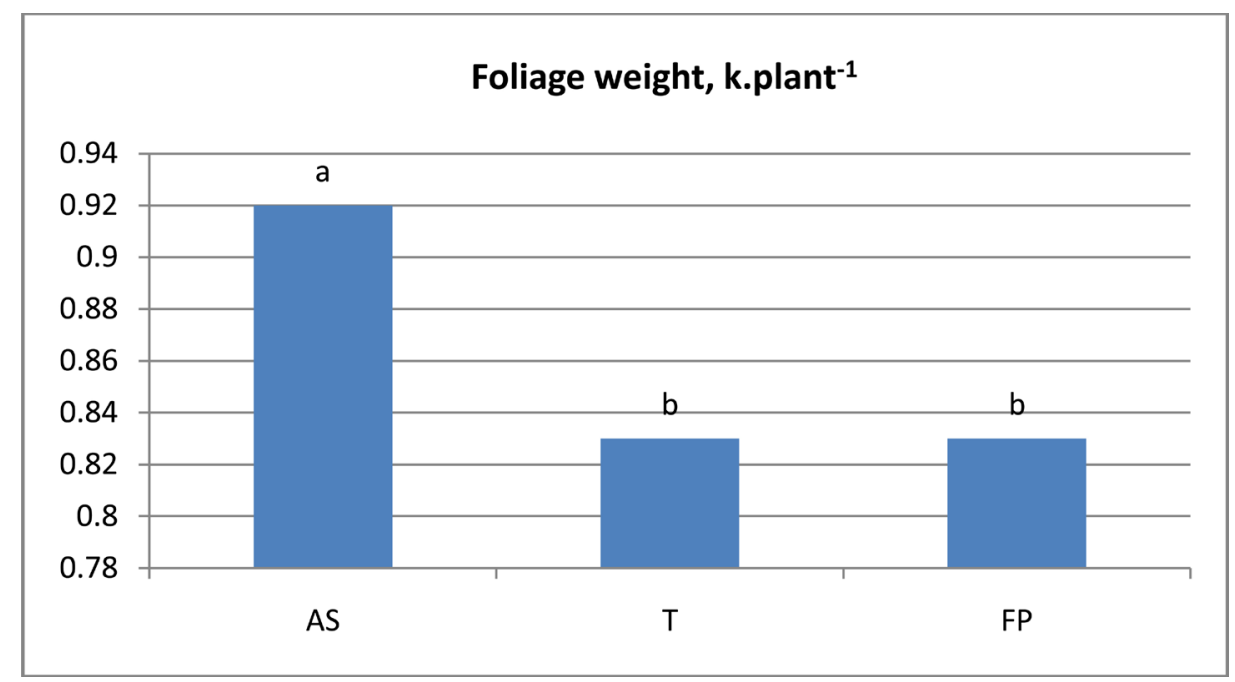

Figure 2. Effect of acetyl salicylic acid and potassium phosphite on the foliage weight.plant ${ }^{-1}$ in three genotypes of sweet potato and two seasons. $\mathrm{T}=$ control; $\mathrm{FP}=$ Potassium phosphite; $\mathrm{AS}=$ acetyl salicylic acid. Values with the same letter are not significant $(\mathrm{p}>0.05)$.

by a pathogen [15]. These include among others, the activation of cell death, the expression of pathogen resistance protein (PR), and the induction of local and systemic disease resistance as reviewed by Ahmad \& Hayat. It is interesting therefore, to continue exploring the signaling pathways of this molecule in the context of disease resistance in crops [16]. It is necessary to evaluate the effect of dose of acetyl salicylic acid on sweet potatoes because as all plant hormones, it requires specificity for its action in inducing defenses in plants or improve agronomic performance. In the present investigation it was found that acetylsalicylic acid increased the weight of the foliage in sweet potato under field conditions, which agrees in part with what was found by Zhang et al. [17] who showed that salicylic acid is related to the longevity of foliage of plants and delayed senescence in Arabidopsis, which could explain the effect of acetylsalicylic acid on fresh weight of sweet potato foliage obtained in this investigation. Not have been able to establish effective comparisons between the results obtained in this study compared to other jobs in sweet potato treated with chemical inducers and plant growth promoters as the role of SA in plant growth has been little studied compared with other plant hormones, but in crops like squash significant increases in total biomass with application of acetylsalicylic acid were obtained, although in this case were also used as treatments, bacterial strains of Bacillus subtilis [18]. Finally, the prospective use of acetylsalicylic acid in sweet potato could be increased, considering that this crop is vegetative propagated by cuttings and there are problems of availability of quality seeds or clonal disease-free at field farmers in which sweet potato is cultivated and where the effect of salicylic acid and other compounds have been tested as immunizing agents or inducers of resistance to various diseases [19]. SA is involved in signal transduction, pondering over the plant resistance to stress and generates significant impact on photosynthesis, transpiration, uptake and transport of ions and plant growth and development [20]; in this aspect, the experimental results indicate the potential utility of SA 
and derived phenolic compounds in the agronomic performance of root crops, as sweet potatoes.

\section{Acknowledgements}

Special thanks to Facultad de Ingenieria Agraria, Industrias Alimentarias y Ambiental (Agrarian Engineering, Food Industry and Environment Faculty), and Vice President for Research of Universidad Nacional José Faustino Sánchez Carrión (Huacho), for the facilities provided to the research. We are also grateful to Dr. Rodomiro Ortiz of SLU (Sweden) by the suggestions made to article.

\section{References}

[1] Eguren, F. (2012) Eficiencia y rendimientos en la agricultura peruana. La revista Agraria, No. 141, 11-13.

[2] Ministerio de Agricultura y Riego (2013) Dinámica agropecuaria 2003-2012. Oficina de Estudios Económicos y Estadísticos (OEEE-MINAGRI), Lima, 193 p.

[3] Raskin, I. (1992) Role of Salicylic Acid in Plants. Annual Review of Plant Biology, 43, 439463. http://dx.doi.org/10.1146/annurev.pp.43.060192.002255

[4] Walters, D.R. (2010) Induced Resistance: Destined to Remain on the Sidelines of Crop Protection? Phytoparasitica, 38, 1-4. http://dx.doi.org/10.1007/s12600-009-0067-y

[5] Lyon, G. (2007) Agents That Can Elicit Induced Resistance. In: Walters, D.R., Newton, A.C. and Lyon G.D., Eds., Induced Resistance for Plant Defense: A Sustainable Approach to Crop Protection, Blackwell Publishing Ltd., Oxford, 9-29.

http://dx.doi.org/10.1002/9780470995983.ch2

[6] Horvath, E., Szalai, G. and Janda, T. (2007) Induction of Abiotic Stress Tolerance by Salicylic Acid Signaling. Journal of Plant Growth Regulation, 26, 290-300. http://dx.doi.org/10.1007/s00344-007-9017-4

[7] Lebeis, S.L., et al. (2015) Salicylic Acid Modulates Colonization of the Root Microbiome by Specific Bacterial Taxa. Science, 349, 860-864. http://dx.doi.org/10.1126/science.aaa8764

[8] Song, G.C., Sim, H.-J., Kim, S.-G. and Ryu, C.-M. (2016) Root-Mediated Transmission of Systemic Acquired Resistance. Annals of Botany, 118, 1-12.

[9] Delaney, T.P., Uknes, S., Vernooij, B., Friedrich, L., Weymann, K., Negrotto, D., Gaffney, T., Gut-Rella, M., Kessmann, H. and Ward, E. (1994) A Central Role of Salicylic Acid in Plant Disease Resistance. Science, 266, 1247-1250. http://dx.doi.org/10.1126/science.266.5188.1247

[10] Rickard, D.A. (2000) Review of Phosphorus Acid and Its Salts as Fertilizer Materials. Journal of Plant Nutrition, 23, 161-180. http://dx.doi.org/10.1080/01904160009382006

[11] Reymond, P. and Farmer, E. (1998) Jasmonate and Salicylate as Global Signals for Defense Gene Expression. Current Opinion in Plant Biology, 1, 404-411. http://dx.doi.org/10.1016/S1369-5266(98)80264-1

[12] Fonseca, C., Zuger, R., Walker, T. and Molina, J. (2002) Estudio de impacto de la adopción de las nuevas variedades de camote liberadas por el INIA, en la costa central Perú. Caso del valle de Cañete, Lima, Perú, Centro Internacional de la Papa (CIP), 24 p.

[13] USAID (2006) Boletín técnico de producción: El Uso del Ácido Salicílico y Fosfonatos (Fosfitos) para Activar el Sistema de Resistencia de la Planta (SAR). Agosto 2006. USAID- 
RED. Oficina FHIA, La Lima, Cortes, Honduras, 4 p.

[14] Balzarini, M.G., Gonzalez, L., Tablada, M., Casanoves, F., Di Rienzo, J.A. and Robledo, C.W. (2008) InfoStat. Manual delUsuario. Editorial Brujas, Córdoba, Argentina.

[15] Dempsey, D.A., Shah, J. and Klessig, D.F. (1999) Salicylic Acid and Disease Resistance in Plants. Critical Reviews in Plant Sciences, 18, 547-575.

http://dx.doi.org/10.1080/07352689991309397

[16] Van Loon, L.C. (2008) Manipulating the Plant's Innate Immune System by Inducing Resistance. Phytoparasitica, 36, 2-3. http://dx.doi.org/10.1007/BF02981323

[17] Zhang, K., Halitschkec, R., Yina, C., Liub, C. and Gan, S.S. (2013) Salicylic Acid 3-Hydroxylase Regulates Arabidopsis Leaf Longevity by Mediating Salicylic Acid Catabolism. PNAS, 110, 1-6. http://dx.doi.org/10.1073/pnas.1302702110

[18] Maldonado-Cruz, D.E., Ochoa-Martínez, D.L. and Tlapal-Bolaños, E. (2008) Efecto del ácido acetil salicílico y Bacillus subtilis en la infección causada por Cucumber Mosaic Virus en calabacita. Revista Chapingo Serie Horticultura, 14, 55-59.

[19] Heil, M. and Bostock, M. (2003) Induced Systemic Resistance (ISR) against Pathogens in the Context of Induced Plant Defenses. Annals of Botany, 89, 503-512. http://dx.doi.org/10.1093/aob/mcf076

[20] Hayat, S. and Ahmad, A. (2013) Salicylic Acid, Plant Growth and Development. Eds. Springer, Springer Science+Business Media, Dordrecht.

\section{Submit or recommend next manuscript to OALib Journal and we will provide best service for you:}

- Publication frequency: Monthly

- 9 subject areas of science, technology and medicine

- Fair and rigorous peer-review system

- Fast publication process

- Article promotion in various social networking sites (LinkedIn, Facebook, Twitter, etc.)

- Maximum dissemination of your research work

Submit Your Paper Online: Click Here to Submit

Or Contact service@oalib.com 